\title{
PENINGKATAN MUTU DAN PRODUKSI IKAN GABUS (Channa striata) DI KELOMPOK PEMBUDIDAYA IKAN HARAPAN KITA DESA JEJANGKIT MUARA
}

\section{Improved Quality and Production of Snakehead (Channa striata) in Harapan Kita Fish Cultivation Group, Jejangkit Muara Village}

\author{
Junius Akbar ${ }^{1 *}$ dan Eka Iriadenta ${ }^{2)}$
}

1)Program Studi Budidaya Perairan Universitas Lambung Mangkurat, ${ }^{2)}$ Program Studi Manajemen Sumberdaya Perairan Universitas Lambung Mangkurat

Jalan A. Yani Km 36 Kotak Pos 6 Banjarbaru, Kalimantan Selatan 70714

*Alamat korespondensi: junius.akbar@ulm.ac.id

(Tanggal Submission: 28 July 2020, Tanggal Accepted : 14 Januari 2021)

\section{Keyword: Abstract :}

Jejangkit Desa Jejangkit Muara salah satu desa yang terletak di kecamatan Jejangkit, Kabupaten Muara, Barito Kuala, Kalimantan Selatan merupakan daerah pengembangan kawasan budi gabus, daya terpadu berbasis agribisnis yang dikembangkan oleh Kabupaten Barito Kuala. double Mata pencaharian penduduk sebagian besar petani, peternak, dan pembudidaya hapa, inkubator ikan, khususnya pembesaran ikan gabus (Channa striata) di kolam tanah. Di desa Jejangkit Muara sudah terbentuk kelompok pembudidaya ikan Harapan Kita. Kelompok pembudidaya ikan ini masih mengalami permasalahan dalam budi daya ikan gabus. Kendala utamanya adalah ketersediaan benih ikan gabus secara kontinyu baik kualitas maupun kuantitas. Salah satu penyebabnya adalah tingginya tingkat kematian benih ikan gabus berukuran 1-3 cm. Permasalahan lain penggunaan pakan ikan rucah berupa ikan sepat rawa. Penggunaan ikan rucah sepat rawa menyebabkan biaya pakan tinggi, kandungan nutrisi berubah-ubah, dan berdampak pada lingkungan. Tujuan kegiatan Program Kemitraan Masyarakat (PKM) memperkenalkan teknologi double hapa sebagai inkubator benih, pemeliharaan dalam hapa $2 \times 3 \mathrm{~m}$, dan penggunaan pakan pellet sebagai pengganti pakan ikan rucah sepat rawa. Tahapan yang dilaksanakan dengan metode difusi ipteks dan substitusi ipteks, melalui penyuluhan, demonstrasi, dan evaluasi. Hasil evaluasi pengetahuan diperoleh $\mathrm{t}$ hit $=$ 9,17 dan tingkat keterampilan $\mathrm{t}$ hit $=6,21>\mathrm{t} \operatorname{tab}(0,05)=2,228$ dan $\mathrm{t} \operatorname{tab}(0,01)=$ 3,169 . Hal ini berarti terjadi peningkatan pengetahuan dan keterampilan setelah dilakukan penyuluhan dan demonstrasi. Hasil evaluasi sikap mitra keseriusan-serius, minat-sangat berminat, dan ambisi-cukup berambisi.

Panduan sitasi / Citation guidance (APPA $7^{\text {th }}$ edition) :

Akbar, J., \& Iriadenta, E. (2021). Peningkatan Mutu dan Produksi Ikan Gabus (Channa Striata) di Kelompok Pembudidaya Ikan Harapan Kita Desa Jejangkit Muara. Jurnal Abdi Insani Universitas Mataram, 8 (1), 1-9. http://doi.org/10.29303/abdiinsani.v8i1.360 


\section{PENDAHULUAN}

Desa Jejangkit Muara merupakan daerah pengembangan kawasan budi daya terpadu berbasis agribisnis yang sedang dikembangkan oleh Kabupaten Barito Kuala. Berdasarkan hasil wawancara dengan ketua Rukun Tetangga (Bapak Durhat) jumlah penduduk di desa Jejangkit Muara berjumlah 1.342 jiwa yang terdiri dari laki-laki 707 jiwa dan perempuan 635 jiwa, dengan jumlah kepala keluarga 304. Mata pencaharian penduduk, sebagian besar adalah petani, peternak, dan pembudidaya ikan khususnya pembesaran ikan gabus (Channa striata) di kolam tanah.

Ikan gabus adalah jenis ikan asli air tawar Indonesia yang tersebar luas di Sumatera, Kalimantan, dan Jawa. Jenis ini memiliki berbagai habitat yang ditemukan di sungai, rawa, kolam, kanal, danau, dan sawah, serta daerah estuaria atau payau (Akbar, 2017; Akbar \& Iriadenta, 2017; Akbar et al, 2018; Akbar \& Iriadenta, 2019). Ikan gabus termasuk ikan konsumsi air tawar yang bernilai ekonomis tinggi (Rp.40.000-85.000/kg) karena sangat digemari masyarakat baik dalam bentuk basah maupun kering (ikan asin). Selain itu, ikan gabus memiliki nilai tambah berupa kandungan protein dan albumin tinggi yang telah terbukti sebagai food supplement untuk mempercepat penyembuhan luka bakar, pasca operasi, meningkatkan status gizi, dan daya tahan anak kurang gizi (Mustafa et al, 2012; Shafri \& Manan, 2012; Mustafa et al, 2013; Kasim et al, 2017).

Ikan gabus menarik untuk dibudidayakan karena beberapa faktor, yaitu harga jual tinggi, pertumbuhan relatif cepat, toleran terhadap kepadatan tinggi, memiliki kemampuan air-breathing (Akbar, 2017; Akbar \& Iriadenta, 2019). Usaha budi daya ikan gabus mulai berkembang di desa Jejangkit Muara, Kecamatan Jejangkit, Kabupaten Barito Kuala, Kalimantan Selatan. Hal ini, dengan dibentuknya kelompok pembudidaya ikan Harapan Kita.

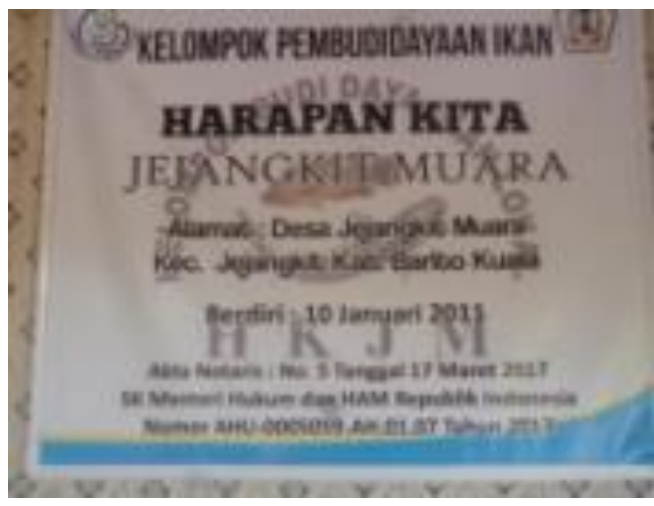

Gambar 1. Kelompok pembudidaya ikan Harapan Kita

Kelompok pembudidaya ikan Harapan Kita masih mengalami permasalahan dalam budi daya ikan gabus. Masalah budi daya ikan gabus di kelompok pembudidaya ikan Harapan Kita adalah tingginya tingkat kematian benih. Hal ini disebabkan benih ikan yang didapatkan dari penangkapan di alam langsung ditebar dalam kolam pembesaran ikan gabus. Ikan gabus mempunyai sifat kanibalisme. Kanibalisme merupakan pemangsaan intraspesifik dengan memangsa spesies yang sama dalam satu populasi (Smith \& Reay, 1991; Baras \& Jobling, 2002; Naumowicz et al, 2017). Kanibalisme dapat menyebabkan tingkat kematian sampai lebih dari $90 \%$ individu (Solomon

\& Udoji, 2011; Naumowicz et al, 2017). Untuk itu, perlu adanya usaha memperkenalkan teknologi double hapa sebagai inkubator benih ikan untuk mengurangi kematian ikan.

Kelompok pembudidaya ikan Harapan Kita masih menggunakan ikan rucah dari ikan sepat rawa (Trichogaster pectoralis) untuk pembesaran ikan gabus. Padahal ikan sepat rawa memiliki nilai tinggi apabila dijadikan ikan sepat rawa kering dan pada musim kemarau ikan sepat rawa tidak ditemukan atau sangat susah diperoleh serta kandungan nutrisi bisa berubah-ubah. Hal ini sangat mempengaruhi produksi ikan. Adapun tujuan kegiatan PKM ini adalah memperkenalkan teknologi double hapa sebagai inkubator benih ikan gabus ukuran 1-3 cm, memelihara benih ukuran juvenil dalam hapa ukuran $2 \times 3$ meter, dan penggunaan pakan pellet sebagai pengganti pakan ikan rucah sepat rawa yang bernilai ekonomis relatif tinggi apabila dijadikan ikan kering. 


\section{METODE KEGIATAN}

Sasaran kegiatan Program Kemitraan Masyarakat (PKM) yaitu kelompok pembudidaya ikan Harapan Kita. Letak lokasi kelompok pembudidaya ikan Harapan Kita terletak di desa Jejangkit Muara, Kecamatan Jejangkit, Kabupaten Barito Kuala, Kalimantan Selatan. Desa Jejangkit Muara berbatasan sebelah utara dengan Kabupaten Banjar, sebalah timur dan selatan dengan Sungai Martapura, sebelah barat dengan Desa Galam Rabah. Jarak Desa Jejangkit Muara dari ibukota Kecamatan Jejangkit 2 km dengan waktu tempuh 5-10 menit. Jarak ke ibukota Kabupaten Barito Kuala berjarak 40 km dengan waktu tempuh 25-30 menit. Sedangkan jarak Desa Jejangkit Muara ke Universitas Lambung Mangkurat 55 km dengan waktu tempuh 30-45 menit.

Pertimbangan memilih kelompok pembudidaya ikan Harapan Kita karena kelompok ini telah melakukan budi daya pembesaran ikan gabus dalam kolam tanah. Kelompok pembudidaya ikan ini masih mengalami permasalahan dalam budi daya ikan gabus. Salah satu permasalahan kelompok pembudidaya ikan Harapan Kita, yaitu tingginya tingkat kematian benih ikan gabus berukuran 1-3 $\mathrm{cm}$.

Metode yang digunakan dalam kegiatan Program Kemitraan Masyarakat (PKM) ini terdiri dari metode penjelasan penyuluhan, metode demonstrasi, dan metode evalusi hasil kegiatan. Sebelum pelaksanaan penyuluhan dan demonstrasi, dilakukan kegiatan sosialisasi dan penyerahan bantuan seperangkat alat untuk memelihara benih ikan gabus dan pakan ikan. Berikut adalah rincian metode kegiatan yang dilaksanakan:

1. Metode Penyuluhan

Metode ini dengan cara mengumpulkan anggota kelompok pembudidayaan ikan Harapan Kita sebagai mitra sasaran. Penyuluhan diterapkan untuk menyampaikan informasi kepada anggota kelompok pembudidaya ikan tentang teknologi double hapa sebagai inkubator benih ikan gabus. Sebelum dan sesudah penyuluhan dilakukan pre test dan post test sehingga diketahui tingkat pemahaman mitra sasaran terhadap materi yang diberikan.

2. Metode Demonstrasi

Metode ini dilakukan dengan melakukan demonstrasi pemasangan dan pemeliharaan benih ikan gabus dalam double hapa. Demonstrasi pemasangan dan pemeliharaan benih ikan gabus ukuran juvenil dalam hapa berukuran $2 \times 3$ meter. Dalam pelaksanaannya melibatkan anggota kelompok pembudidayaan ikan Harapan Kita.

3. Metode Evaluasi

Evaluasi dilakukan untuk mengetahui tingkat keberhasilan kegiatan Program Kemitraan Masyarakat (PKM) ini. Metode ini berupa evalusi perubahan tingkat pengetahuan dan tingkat keterampilan tentang perbaikan mutu dan peningkatan produksi ikan gabus melalui teknologi double hapa sebagai inkubator benih. Evaluasi dilakukan sebelum, selama, dan sesudah kegiatan PKM ini dilakukan.

\section{HASIL DAN PEMBAHASAN}

Kegiatan Program Kemitraan Masyarakat (PKM) dilaksanakan pada kelompok pembudidaya ikan Harapan Kita, yang berada di desa Jejangkit Muara, Kecamatan Jejangkit, Kabupaten Barito Kuala, Kalimantan Selatan. Kegiatan PKM dilaksanakan melalui beberapa tahap, yaitu persiapan penyelesaian administrasi surat menyurat, sosialisasi kepada kelompok pembudidaya ikan, penyuluhan, demonstrasi, evaluasi, dan pelaporan. 
Masalah budi daya ikan gabus di kelompok pembudidaya ikan Harapan Kita adalah tingginya tingkat kematian benih ikan gabus. Hal ini disebabkan benih ikan langsung ditebar dijadikan satu dalam kolam pembesaran ikan gabus yang dimiliki sasaran mitra. Untuk itu, perlu adanya usaha memperkenalkan teknologi double hapa sebagai inkubator benih ikan untuk mengurangi tingkat kematian ikan.

Kegiatan inti dari Program Kemitraan Masyarakat (PKM) ini adalah dilakukannya penyuluhan dan demonstrasi teknologi double hapa sebagai inkubator benih dan pemeliharaan ikan dalam hapa ukuran $2 \times 3 \mathrm{~m}$ yang diberi pakan pellet. Teknologi double hapa terdiri dari dua buah hapa yang memiliki ukuran berbeda. Hapa bagian dalam relatif lebih kecil dari hapa bagian luar. Hapa bagian dalam memiliki ukuran 1x1x1 m sedangkan hapa bagian luar memiliki ukuran $2 \times 1 \times 1 \mathrm{~m}$.

Benih ikan gabus (Channa striata) berukuran panjang sekitar $1 \mathrm{~cm}$ ditebar dalam hapa bagian dalam. Setelah lama pemeliharaan 14 hari, benih ikan gabus tersebut dipindahkan ke hapa bagian luar yang lebih besar ukurannya. Ikan diberi pakan pellet PF 500 secara ad satiasi yang frekuensi pemberiannya dua kali sehari pada pagi hari (jam 07:00-08:00 Wita) dan sore hari (sekitar jam 17:0018:00 Wita).
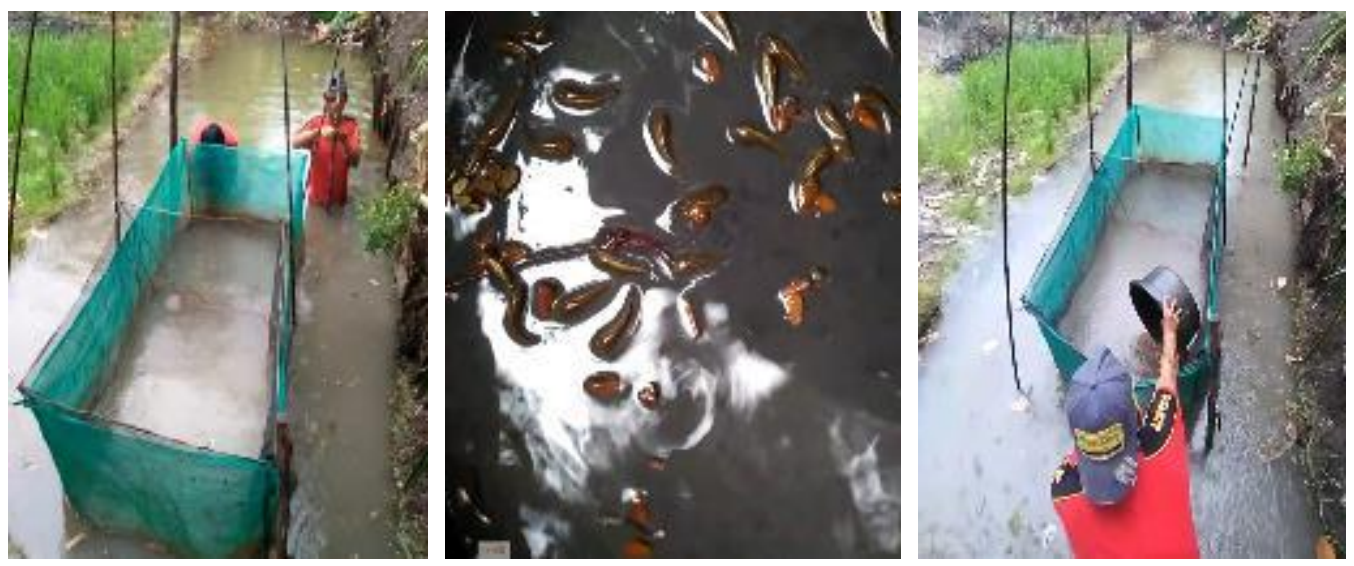

Gambar 2. Pemeliharaan benih ikan gabus ukuran $1 \mathrm{~cm}$ dalam double hapa

Hasil inovasi teknologi double hapa sebagai inkubator benih ikan gabus, di mana benih ikan gabus berukuran $1 \mathrm{~cm}$ yang diletakkan dalam double hapa, dari 600 ekor benih ikan gabus yang ditebar di dalam double hapa selama 14 hari, jumlah benih ikan gabus yang mati hanya sebanyak 17 ekor atau sekitar 2,8\%. Setelah benih ikan gabus mencapai ukuran 3-5 cm, benih ikan gabus dipindahkan ke hapa bagian luar dari double hapa. Pemeliharaan dilaksanakan selama kurang lebih 1,5-2 bulan. Ikan diberi pakan PF 800 secara ad satiasi pada pagi hari (sekitar jam 07:00 Wita) dan sore hari (sekitar jam 17:00 Wita).

Penggunaan teknologi double hapa banyak memberikan keuntungan bagi mitra sasaran berupa benih ikan gabus sebelum ditebar ke kolam sudah mengalami penyesuaian yang lebih lama dan ukuran benih ikan gabus relatif lebih merata. Dengan lebih merata ukuran dan lebih banyak benih ikan yang ditebar, maka akan terjadi peningkatan produksi benih ikan gabus yang dipelihara. Pada akhirnya, akan berdampak pada peningkatan taraf hidup dan kesejahteraan sasaran mitra. 

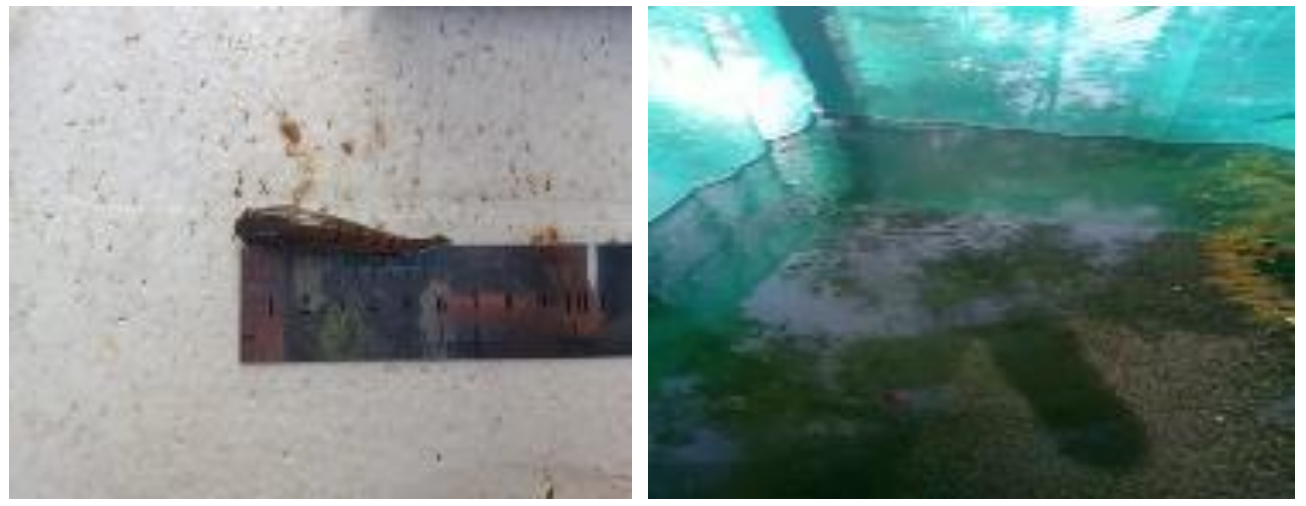

Gambar 3. Pemeliharaan benih ikan gabus ukuran 3-5 cm

Pemeliharaan benih juvenil ikan gabus di dalam hapa ukuran $2 \times 3$ meter dilakukan dalam dua hapa yang berbeda. Satu hapa diberi pakan pellet (pakan merk compeed) dan yang satunya lagi diberi pakan rucah (ikan sepat rawa). Pemanfaatan pakan pellet komersial atau pakan formulasi sekarang populer, terutama untuk ikan karnivora seperti ikan gabus, untuk mengurangi ketergantungan pada ikan rucah, biaya pakan, dan dampak lingkungan.
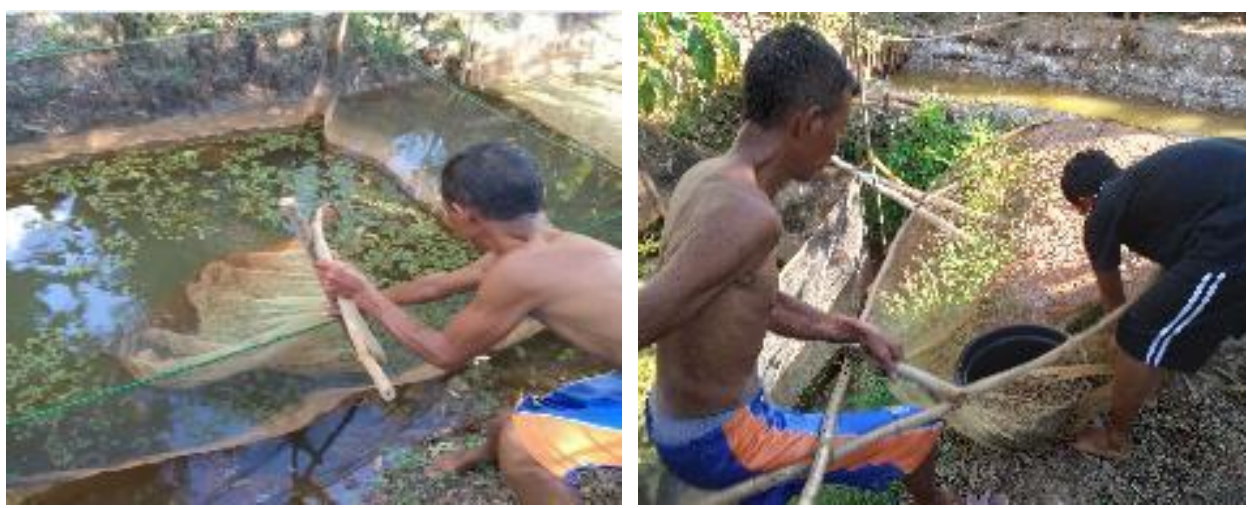

Gambar 4. Sampling pemeliharaan ikan gabus dalam hapa $2 \times 3$
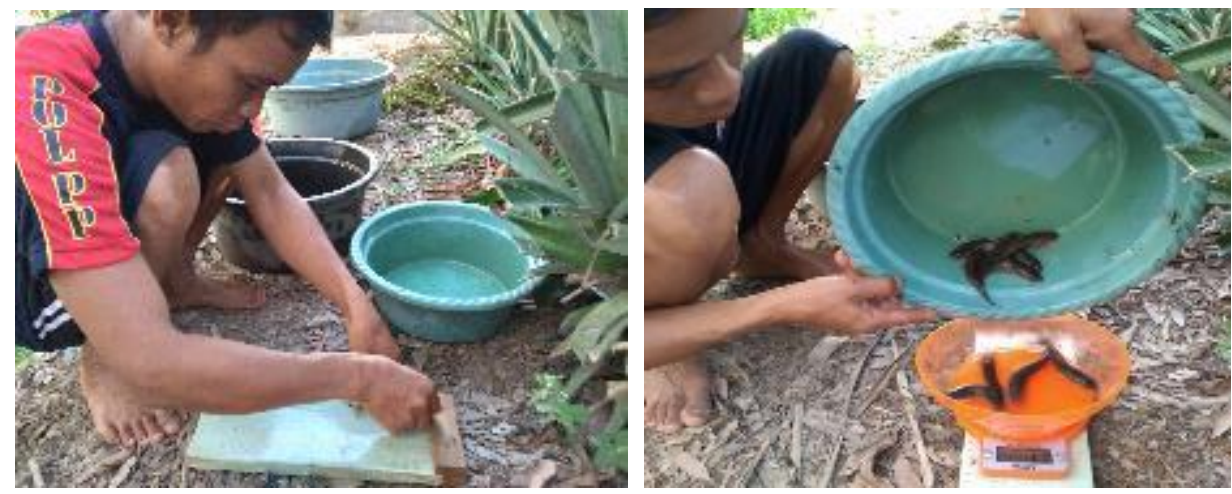

Gambar 5. Pengukuran panjang dan bobot ikan gabus

Studi tentang penggantian ikan rucah oleh pakan pellet pada ikan gabus menunjukkan tingkat pertumbuhan yang lebih baik dan lebih menguntungkan (Hien et al, 2015; Hien et al, 2016; Hien et al, 2017). Mengganti ikan rucah dengan pakan pellet memberi lebih banyak manfaat dalam biaya makan dan mengurangi ketergantungan pada pasokan ikan rucah. Ikan gabus dapat menggunakan pakan pellet (protein kasar 40\%-45\%), pertumbuhan yang lebih baik dan biaya makan lebih sedikit daripada 
ikan rucah (Wee \& Tacon, 1982; Mohanty \& Samantaray, 1996; Kumar et al, 2010; Kumar \& Haniffa, 2015). Namun hasil pelaksanaan PKM yang dilakukan di kelompok pembudidaya ikan Harapan Kita, benih ikan gabus yang diberi pakan ikan rucah kondisi ikannya lebih gesit dibandingkan dengan ikan yang diberi pakan pellet. Sedangkan pertumbuhan panjang dan bobot ikan diantara keduanya tidak berbeda nyata. Hal ini diduga disebabkan benih ikan gabus yang dipelihara dalam hapa ukuran $2 \times 3 \mathrm{~m}$, sama-sama di letakkan dalam satu kolam yang sama.

Evaluasi kegiatan PKM ini terdiri dari evaluasi tingkat pengetahuan, keterampilan, dan sikap. Evaluasi tingkat pengetahuan secara individu, diberikan sebelum dan sesudah kegiatan penyuluhan. Hasil evaluasi tingkat pengetahuan terjadi peningkatan setelah diberikan penjelasan secara teori atau penyuluhan. Didapatkan nilai thit $=9,17>t \operatorname{tab}(0,05)=2,228$ dan $t \operatorname{tab}(0,01)=3,169$. Hal ini berarti bahwa terjadi peningkatan tingkat pengetahuan peserta kelompok pembudidaya ikan Harapan Kita (mitra) setelah diberikan penjelasan secara teori atau penyuluhan.
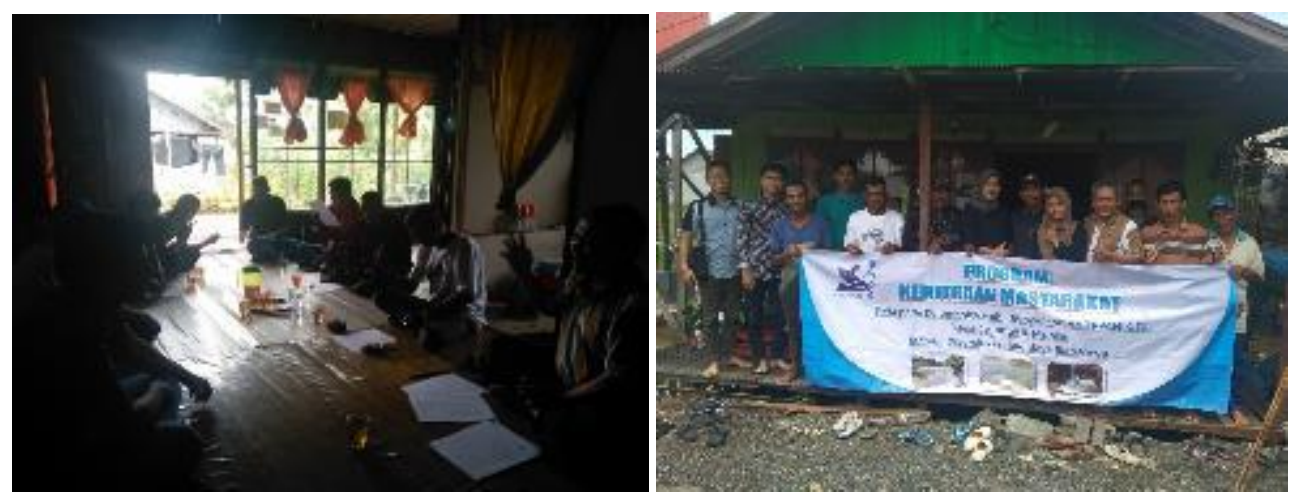

Gambar 6. Evaluasi tingkat pengetahuan

Evaluasi tingkat keterampilan dilakukan dengan cara menilai dan mengamati tingkat keterampilan peserta mitra dari awal dan akhir kegiatan. Hasil evaluasi tingkat keterampilam diperoleh nilai $\mathrm{t}$ hit $6,21>\mathrm{t}$ tab $(0,05)=2,228$ dan $\mathrm{t} \operatorname{tab}(0,01)=3,169$. Hal ini berarti terjadi peningkatan keterampilan peserta mitra setelah dilakukan demonstrasi pemeliharaan benih ikan gabus dalam hapa ukuran $2 \times 3$ meter.

Evaluasi sikap dibagi menjadi tiga penilaian, yaitu keseriusan, minat, dan ambisi. Hasil evaluasi sikap tampak bahwa kelompok pembudidaya ikan Harapan Kita memiliki sikap yang sangat mendukung terhadap kegiatan yang dilaksanakan. Hal ini didukung oleh analisis situasi yang ada dan kemanfaatan bagi mereka. Hasil evaluasi terhadap sikap didapatkan hasil keseriusan-sangat serius, minat-berminat, dan ambisi-cukup berambisi.

Faktor-faktor yang menjadi penghambat atau kendala dalam pelaksanaan kegiatan PKM ini adalah:

a) Masyarakat dan anggota kelompok pembudidaya ikan Harapan Kita masih terpaku pada penangkapan ikan gabus di alam.

b) Kelompok pembudidaya ikan Harapan Kita belum sepenuhnya memahami tentang pentingnya aspek pembenihan ikan gabus.

c) Kelompok pembudidaya ikan Harapan Kita belum memiliki keterampilan dalam penyediaan pakan alami untuk benih ikan gabus.

d) Kelompok pembudidaya ikan Harapan Kita masih terpaku pada penggunaan pakan rucah ikan sepat rawa yang memiliki nilai ekonomis relatif tinggi apabila dijadikan ikan sepat kering. 
e) Kurangnya modal dan kemudahan permodalan bagi kelompok pembudidaya ikan Harapan Kita menjadi penghambat atau kendala sebagai alasan bagi mereka untuk mengembangkan usahanya, disisi lain lahan yang tersedia masih sangat luas.

f) Kurangnya pembinaan kepada kelompok pembudidaya ikan secara intensif.

Faktor-faktor yang mendukung kelancaran kegiatan PKM ini adalah:

a) Lokasi kegiatan PKM ditetapkan sebagai daerah pengembangan kawasan budi daya terpadu berbasis agribisnis.

b) Kelompok pembudidaya ikan Harapan Kita sudah mengenal secara umum pemeliharaan pembesaran ikan gabus dalam kolam tanah.

c) Tersedianya lahan yang cukup luas untuk dijadikan kolam dan ketersediaan sumber air dari Sungai Martapura.

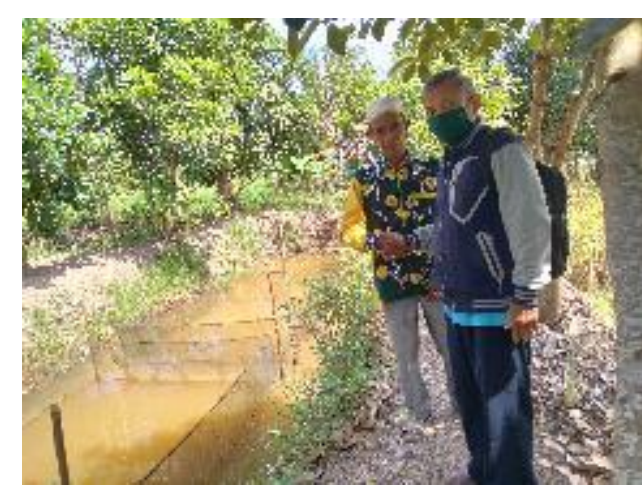

Gambar 7. Serah terima kepada ketua kelompok Harapan Kita

Pada masa pandemik Covid 19 ini, kelompok pembudidaya ikan Harapan Kita (mitra) terbatas penjualan ikan di pasar tradisional, karena adanya ketentuan menjalankan Ekonomi Minim Kontak (less contact economy). Untuk itu, perlu adanya usaha memperkenalkan, mengadopsi, dan menerapkan pemasaran berbasis teknologi digital selain mengadopsi teknologi double hapa, pemeliharaan dalam hapa $2 \times 3$ meter, pembesaran dalam kolam tanah, dan penggunaan pakan pellet sebagai pengganti pakan rucah sepat rawa yang bernilai ekonomis relatif tinggi.

\section{KESIMPULAN DAN SARAN}

\section{Kesimpulan}

Beberapa poin kesimpulan yang dapat diperoleh melalui kegiatan pengabdian kepada masyarakat ini adalah sebagai berikut :

1. Telah dilakukan kegiatan PKM pada kelompok pembudidaya ikan Harapan Kita, Desa Jejangkit Muara, Kecamatan Jejangkit, Barito Kuala berupa penerapan teknologi double hapa sebagai inkubator untuk meningkatkan produksi benih ikan gabus.

2. Kegiatan PKM meliputi penyuluhan, demonstrasi dan evaluasi serta penyerahan paket teknologi double hapa dan hapa ukuran $2 \times 3$ meter sebanyak untuk pemeliharaan ikan gabus.

3. Terjadi perubahan yang semakin meningkat pengetahuan dan keterampilan kelompok pembudidaya ikan Harapan Kita, pada akhirnya meningkatkan mutu dan produksi ikan gabus.

\section{Saran}

Beberapa poin saran yang dapat diperoleh melalui kegiatan pengabdian kepada masyarakat ini adalah sebagai berikut :

1. Perlu adanya pembinaan tentang penanganan pra dan pasca penjualan ukuran benih dan ukuran konsumsi ikan gabus secara teknologi digital untuk menjalankan ekonomi minim kontak (less contact economy) selama masa pandemik Covid 19 ini.

2. Perlu adanya kegiatan pembinaan dari instansi terkait secara intensif. 


\section{UCAPAN TERIMA KASIH}

Ucapan terima kasih disampaikan kepada Direktorat Riset dan Pengabdian Masyarakat. Deputi Bidang Penguatan Riset dan Pengembangan. Kementerian Riset dan Teknologi / Badan Riset dan Inovasi Nasional atas bantuan dana yang diberikan melalui Program Kemitraan Masyarakat (PKM) dengan Nomor: 057/SP2H/PPM/DRPM/2020, tanggal 23 Maret 2020.

\section{DAFTAR PUSTAKA}

Akbar, J. (2017). Potensi, Peluang, dan Tantangan Pengembangan Perikanan Rawa di Kalimantan Selatan. Lambung Mangkurat University Press, Banjarmasin.

Akbar, J., \& Iriadenta, E. (2017). Domestikasi Empat Jenis Ikan Genus Channa (C. striata; C. micropeltes; C. pleuropthalmus, dan C. gacua) sebagai Upaya Optimalisasi Perairan Rawa. Laporan Hasil Penelitian Dasar Unggulan Perguruan Tinggi (Tahun ke-1).

Akbar, J., Iriadenta, E., \& Nur., A. (2018). Domestikasi Empat Jenis Ikan Genus Channa (C. striata; C. micropeltes; C. pleuropthalmus, dan C. gacua) sebagai Upaya Optimalisasi Perairan Rawa. Laporan Hasil Penelitian Dasar Unggulan Perguruan Tinggi (Tahun ke-2).

Akbar, J., \& Iriadenta, E. (2019). Feeding habits, length-weight relation, and growth pattern of snakehead fish (Channa striata) from the rice field of Jejangkit Muara Village, Barito Kuala Regency, South Kalimantan Province, Indonesia. International Journal of Engineering Research \& Science (IJOER), 5 (1), 18-21.

Baras, E \& Jobling., M. (2002). Dynamics of intracohort cannibalism in cultured fish. Aquaculture Research, 33, 461-479.

Hien, T.T.T., Be, T.T., Lee, C.M., \& Bangtson, D.A., (2015). Development of formulated diets for snakehead (Channa striata and Channa micropeltes): Can phytase and taurine supplementation increase use of soybean meal to replace fish meal?. Aquaculture. 448, 334-340.

Hien, T.T.T., Trung, N.H.D., Tam, B.M., Chau, V.M.Q., Huy, N.H., Lee, C.M., \& Bengtson, D.A. (2016). Replacement of freshwater small-size fiah by formulated feed in snakehead (Channa striata) aquaculture: Experimental and commercial-scale pond trials, with economic analysis. Aquaculture Reports. 4, 42-47.

Hien, T.T.T., Tam, B.M., Tu, T.L.C., \& Bengtson, D.A. (2017). Weaning methods using formulated feeds for snakehead (Channa striata and Channa micropeltes) larvae. Aquaculture Research, 1-9.

Kasim, V.N., Pateda, S.M., Hadju, V. \& Jafar, N. (2017). Suplementation of snakehead fish extract on nutritional status and immunology among stroke patients. Jurnal Gizi Klinik Indonesia. 13 (3): 91-98.

Kumar, D., Marimuthu, K., Haniffa, M.A., \& Sethuramalingam, T.A. (2010). Optimum dietary protein requirement of striped murrel Channa striatus fry. Malaysian Journal of Science. 29 (1): 52-61.

Kumar, D and Haniffa, M.A. (2015). Nutritional protein requirement of striped murrel Channa striatus fingerling fed on different protein level diets. International Research Journal of Natural and Applied Sciences. 2 (2): 152-172.

Mohanty, S.S., \& Samantaray, K. (1996). Effect of varying levels of dietary protein on the growth performance and feed conversion efficiency of snakehead Channa striata fry. Aquaculture Nutrition, 2, 89-94.

Mustafa, A., Widodo, M.A., \& Kristianto, Y. (2012). Albumin and zinc content of snakehead fish (Channa striata) extract and its role in health. International Journal of Science and Technology, 1(2), 18. 
Mustafa, A., Sujuti, H., Permatasari, N., \& Widodo, M.A. (2013). Determination of nutrient contents and amino acid composition of Pasuruan Channa striata Extract. International Journal of Science and Technology, 2(4), 1-11.

Naumowicz, K, Pajdak, J., Majewska, E.T., \& Szarek, J. (2017). Intracohort cannibalism and methods for its mitigation in cultured freshwater fish. Rev Fish Biol Fisheries, 27, 193-208.

Shafri, M.A., \& Manan, M.J.A. (2012). Therapeutic potential of the haruan (Channa striatus): from food to medicinal uses. Mal. J .Nutr, 18(1), 125-136.

Smith, C \& Reay, P. (1991). Cannibalism in teleost fish. Reviews in Fish Biology and Fisheries, 1, 41-64.

Solomon, R.J., \& Udoji, F.C. (2011). Canibalism among cultured African catfishes (Heterbranchus longifillis and Clarias gariepinus). Nature and Science,9 (9), 1-13.

Wee, K.L \& Tacon, A.G.J. (1982). Apreliminary study on the dietary protein requirement of juvenile snakehead. Bulletin of the Japanese of Scientific Fisheries, 48(10), 1463-1468. 